\title{
MULTIVARIATE ANALYSIS OF MORPHOLOGICAL TRAITS OF THE NIGERIAN MUSCOVY DUCKS (CAIRINA MOSCHATA)
}

\author{
ANÁLISIS MULTIVARIANTEDE CARACTERES MORFOLÓGICOS \\ DE PATOS MUSCOVY NIGERIANOS (CAIRINA MOSCHATA)
}

\author{
Oguntunji, A.O. ${ }^{1 *}$ and Ayorinde, K.L. ${ }^{2}$ \\ 'Department of Animal Science and Fisheries Management. Bowen University. Iwo. Osun State. Nigeria. \\ *abelmendel@yahoo.co.in \\ 2Department of Animal Production. University of Ilorin. Ilorin. Kwara State. Nigeria. tomjay97@yahoo.co.in
}

\section{ADDITIONAL KEYWORDS}

Ecotypes. Euclidean distance.

\section{SUMMARY}

This study was designed to investigate the possibility of classifying Nigerian Muscovy ducks into distinct ecotypes using stepwise discriminant analysis and Euclidean distance. Data were collected on ten morphological traits (body weight, body length, body girth, wing length, shank length, shank circumference, thigh length, total leg length, bill length and bill width) of one thousand and twenty (1020) adult Muscovy ducks comprising 203, 598 and 289 randomly sampled ducks from the rain forest, derived savanna and Guinea savanna ecotypes, respectively. The results of the descriptive statistics revealed highly $(p<0.001)$ significant effects of ecotype on eight of the morphological traits except bill width and body length. Stepwise discriminant analysis indicated that bill length and body length had highest discriminating powers among the six distinguishing variables. Result of the cross validation of the correct assignment of ducks into distinct ecotypes was low; $53.7,41.8$ and $42.3 \%$ of samples drawn from the rain forest, derived savanna and Guinea savanna ecotypes were correctly classified into their expected ecotypes. Euclidean distance between ecotypes was small; shortest distance was between rain forest and derived savanna ducks (2010) while the longest distance (3758) was between rain forest and Guinea savanna ducks. It is evident that due to the low classification success rate of discriminant analysis and short Euclidean genetic distance between ecotypes, they could not be classified into distinct ecotypes

\author{
Palabras clave adicionales \\ Distancia euclidiana. Ecotipos.
}

on the bases of morphostructural traits and appreciable heterosis is practically impossible from crossing Nigerian Muscovy ducks originating from different ecotypes.

\section{RESUMEN}

Este estudio fue realizado para investigar la posibilidad de clasificar los patos Muscovy nigerianos en distintos ecotipos utilizando el análisis discriminante secuencial y la distancia euclidiana. Se obtuvieron datos de diez caracteres morfologicos (peso, longitud y perímetro corporal, longitud del ala, longitud y circunferencia del tarso, longitud del muslo, longitud total de la pierna, longitud y anchura del pico) de 1020 patos Moscovy adultos obtenidos al azar en los ecotipos de bosque lluvioso (203), de sabana derivada (598) y de sabana de Guinea (289). La estadística descriptiva reveló $(p<0,001)$ la influencia del ecotipo sobre ocho de las medidas estudiadas, exceptuando la amplitud del pico y longitud corporal. El análisis discriminante secuencial puso de manifiesto que el mayor poder discriminante corresponde a las longitudes del pico y del cuerpo. La validación cruzada puso de manifiesto una baja asignación correcta a los correspondientes ecotipos; el 53,$7 ; 41,8$ y $42,3 \%$ de las muestras fueron atribuidas correctamente a los ecotipos bosque lluvioso, sabana derivada y sabana de Guinea respectivamente. La distancia euclidiana entre ecotipos resultó pequeña, la más corta se 
registró entre el ecotipo bosque lluvioso y el savana derivada (2010) mientras que la distancia mayor, se registró entre los patos del bosque lluvioso y los de la sabana Guinea. Es evidente que debido al escaso éxito de la clasificación del análisis discriminante y la pequeña distancia euclidiana, los posibles ecotipos estudiados no pueden considerarse diferentes sobre la base de caracteres morfoestructurales y la obtención de una apreciable heterosis es prácticamente imposible a partir del cruzamiento de estos ecotipos nigerianos.

\section{INTRODUCTION}

Among domesticated avian species in Nigeria, duck was ranked third with an estimated population of 9553911 after chicken (101676 710) and guinea fowl (16 976 907), respectively (NBS, 2012). Muscovy duck (Cairina moschata) and common duck (Anas platyrhynchos) popularly known as local and exotic duck, respectively are the most common genera of ducks reared in Nigeria. Of these two genera, Muscovy duck is more numerous with significant presence all over the country (Nwanta et al., 2006; Adeyemi et al., 2008); constituting $74 \%$ of all ducks in Nigeria (Adesope and Nodu, 2002).

This indigenous waterfowl is an integral part of local poultry sector in Nigeria, and are concentrated mostly in rural areas in the hands of small-holder peasants. Similarly to the prevailing neglect of other indigenous birds, empirical researches geared towards its development, conservation and improvement are scanty. Information on genetic attributes of a species is pivotal to its conservation, characterization, improvement and efficient utilization. This vital information could be accessed through biochemical, immunological, molecular and morphological characteristics.

Genetic characterization based on molecular assessment had been reported to be the most common method to evaluate genetic diversity between and within livestock breeds, but needs high technology and cost (Wimmers et al., 2000; Romanov and Weigend, 2001; Hillel et al., 2003). Researchers also use a method based on morphological characters that are easy to monitor, low-cost and provide reliable racial discriminants (Al-Atiyat, 2009). Herrera et al. (1996) corroborated this that morphological variables are easy to monitor and may facilitate the use of ethnological characterization and at the same time establish racial discrimination.

The underlying complex biological mechanisms connected with the formation, development and functions of morphological traits are too complex to be analysed and interpreted through simple univariate and bivariate statistical methods (Oguntunji, 2013). The report of $\mathrm{Wu}$ and Lin (2006) buttressed this assertion that most of the biological, biomedical and agricultural traits were complex and were under the control of interaction of genes, each with a small effect and of environmental factors. Since univariate statistical analysis tends to analyse each variable separately and does not explain how the population under investigation differs when all measured variables were considered jointly (Dossa et al., 2007); therefore, it becomes imperative to employ various multivariate techniques that can analyse many variables simultaneously.

Multifactorial analyses of morphological traits have been proved to be suitable in assessing the variation within a population and can differentiate different population types when all measured morphological variables are considered simultaneously (Traoré et al., 2008; Yakubu and Ibrahim, 2011). Discriminant analysis is one of the multivariate techniques commonly used for analysing many variables simultaneously. Discriminant analysis encompasses procedures for classifying observations into groups (i.e. predictive discriminant analysis) and describing the relative importance of variables for distinguishing among groups (Lix and Sojobi, 2010). Researchers 


\section{MULTIVARIATE ANALYSIS OF MUSCOVY DUCKS}

have employed this multivariate analysis technique extensively for discriminating livestock species into breeds and ecotypes (Agaviezor et al., 2012; Ogah et al., 2011; Yakubu et al., 2010). Against this background, this study was conducted to investigate the possibility of using discriminant analysis of morphological traits for separation of Nigerian Muscovy ducks to different ecotypes.

\section{MATERIALS AND METHODS}

\section{EXPERIMENTAL ANIMALS}

Adult male and female Muscovy ducks used in this study were owned by smallscale farmers. They were mostly managed extensively with little or no supplementary feeding and medication. Only adult ducks which were confirmed by the owners to have commenced laying in the case of females, and males that have sired offspring at least once were involved in the study in order to ensure that matured ducks were used since their ages could not be determined. Besides, data were collected only on apparently healthy birds.

\section{DATACOLLECTION, SAMPLESIZE AND STUDY AREA}

Morphological data used for the analyses were collected on one thousand and twenty (1020) adult male and female Nigerian Muscovy ducks. They comprise 203, 519 and 298 Muscovy ducks randomly drawn from the rain forest, derived savanna and Guinea savanna ecotypes or agro-ecological zones (AEZs), respectively. The climatic conditions of the study area have been described by Oguntunji et al. (2008), Yakubu (2011) and Ogah et al. (2011).

Measurements were taken on body weight and nine other morphological traits: body girth, body length, wing length, shank length, shank circumference, thigh length, total leg length, bill length and bill width. The anatomical references of these metric traits were as described by Yakubu (2011),
Ogah et al. (2011) and Oguntunji (2013).

The body length, body girth, wing length, shank length, thigh length, bill length, bill width, total leg length were measured with the aid of a flexible tape rule in centimeters while body weight measurement was taken using a $10 \mathrm{~kg}$ weighing scale.

\section{STATISTICAL ANALYSES}

Morphological data collected on body weight and nine linear body parameters of each sex and ecotype were analyzed using the following fixed effect model:

$$
Y_{B j}=\mu+S_{j}+G_{j}+e_{B j}
$$

onde:

$Y_{B j}=$ individual observation;

$\mu=$ fixed overall mean;

$\mathrm{S}_{\mathrm{i}}=$ effect of sex (= male, female);

$\mathrm{G}_{\mathrm{i}}=$ effect of ecotype $(\mathrm{i}=$ rain forest, derived savanna, Guinea savanna);

$\mathrm{e}_{\mathrm{Bj}}=$ experimental error, assumed to be independently, identically and normally distributed, with zero mean and constant variance, i.e. ${ }_{B B}$ nd $\left(0, r^{2}\right)$.

Differences between means were accessed using Duncan's Multiple Range Test (DMRT).

Stepwise discriminant procedure was used in order to identify morphological characters with high discriminatory power using ecotype as the separating factor. The relative discriminating ability of the morphological traits was assessed using the level of significance $(\mathrm{Pr}>\mathrm{F})$, Wilk's Lambda and F-statistics (F-to-remove). The effectiveness of the unstandardized canonical discriminant function to classify ducks into separate ecotypes was indicated as the percentage of correct assignment of ducks. As correct classification rates tend to be overestimated when discriminant analysis are validated with the same sample used to generate them (Tabachnick and Fidell, 2007), thus necessitating the use of crossvalidation table, classification success rate 


\section{OGUNTUNJI AND AYORINDE}

was therefore evaluated based on the percentage of individual duck correctly classified into different ecotypes through cross-validation test. All statistical analyses were performed using the SPSS (2001) version 16.

\section{RESULTSANDDISCUSSION}

There was significant $(\mathrm{p}<0.001)$ effect of sex on all the morphological traits in favour of males (table I). Significant differences in body weight and other linear body measurements in favour of male is consistent with the reports of previous studies on Muscovy ducks(Yakubu, 2011), Musk duck(McCracken et al., 2000) and other water birds such as Great Comorants (Phalacrocorax carbo) (Liordos and Goutner, 2008) and Carlifornia Gulls (Larus carlifonicus) (Herring et al., 2010).

In most sexually dimorphic species, males appear bigger in size and more conspicuous compared to their female counterparts (Ajayi et al., 2012). The genderinfluenced differences reported for all the morphological traits in favour of male could be adduced to the usual between-sex differential hormonal effects on growth (Ajayi et al., 2012). In addition, Kharel and Arboleda (1986) attributed sexual dimorphism in Muscovy ducks in part to the effect of sex-linked as well as autosomal genes. The significantly longer body length and higher mean values for body girth in males are indicative of meatiness.

The results of the univariate statistics of the morphometric traits of the Nigerian Muscovy ducks (table II) revealed highly significant $(\mathrm{p}<0.001)$ effects of ecotype on eight of the morphological variables examined except bill width and body length. Comparison of the morphological traits of the ecotypes showed that highest mean values were recorded for rain forest ducks in body weight, body girth, wing length, shank circumference, thigh length, bill length and total leg length; Guinea savanna ducks in shank length while bill width was highest in the derived savanna and Guinea savanna ducks.

The higher mean values recorded for the rain forest ducks in five morphological variables which are indicator of body size, accentuate further the superior body weight of rain forest duck compared to others. The

Table I. Descriptive statistics of the morphological traits of adult Nigerian Muscovy ducks. (Estadística descriptiva de los caracteres morfológicos de patos Muscovy nigerianos adultos).

\begin{tabular}{|c|c|c|}
\hline Trait/Sex & № & Mean $\pm S D$ \\
\hline \multicolumn{3}{|c|}{ Body weight $(\mathrm{kg})$} \\
\hline Male & 287 & $2.64 \pm 0.37^{a}$ \\
\hline Female & 733 & $1.60 \pm 0.25^{b}$ \\
\hline \multicolumn{3}{|c|}{ Body girth (cm) } \\
\hline Male & 287 & $46.93 \pm 2.92^{\mathrm{a}}$ \\
\hline Female & 733 & $38.70 \pm 2.99^{b}$ \\
\hline \multicolumn{3}{|c|}{ Body length $(\mathrm{cm})$} \\
\hline Male & 287 & $30.69 \pm 2.87^{a}$ \\
\hline Female & 733 & $23.96 \pm 2.43^{b}$ \\
\hline \multicolumn{3}{|c|}{ Wing length $(\mathrm{cm})$} \\
\hline Male & 287 & $35.23 \pm 3.80^{\mathrm{a}}$ \\
\hline Female & 733 & $26.71 \pm 2.86^{b}$ \\
\hline \multicolumn{3}{|c|}{ Shank length (cm) } \\
\hline Male & 287 & $5.71 \pm 0.67^{a}$ \\
\hline Female & 733 & $4.57 \pm 0.56^{b}$ \\
\hline \multicolumn{3}{|c|}{ Shank circumference (cm) } \\
\hline Male & 287 & $5.33 \pm 0.58^{a}$ \\
\hline Female & 733 & $4.35 \pm 0.40^{b}$ \\
\hline \multicolumn{3}{|c|}{ Thigh length $(\mathrm{cm})$} \\
\hline Male & 287 & $12.14 \pm 1.24^{a}$ \\
\hline Female & 733 & $9.90 \pm 1.21^{b}$ \\
\hline \multicolumn{3}{|c|}{ Bill length $(\mathrm{cm})$} \\
\hline Male & 287 & $5.94 \pm 0.54^{a}$ \\
\hline Female & 733 & $5.03 \pm 0.42^{b}$ \\
\hline \multicolumn{3}{|c|}{ Bill width $(\mathrm{cm})$} \\
\hline Male & 287 & $3.44 \pm 0.30^{\mathrm{a}}$ \\
\hline Female & 733 & $3.10 \pm 0.25^{b}$ \\
\hline \multicolumn{3}{|c|}{ Total leg length $(\mathrm{cm})$} \\
\hline Male & 287 & $17.83 \pm 1.37^{\mathrm{a}}$ \\
\hline Female & 733 & $14.55 \pm 1.59^{b}$ \\
\hline
\end{tabular}

${ }^{a b}$ Within each trait, means with different superscripts are significantly different $(p<0.001)$. 


\section{MULTIVARIATE ANALYSIS OF MUSCOVYDUCKS}

Table II. Descriptive statistics (mean $\pm S D$ ) of the morphologic traits of Nigerian Muscovy duck ecotypes. (Estadística descriptiva (media $\pm \mathrm{SD}$ ) de los caracteres morfológicos de ecotipos de patos Muscovy nigerianos adultos).

\begin{tabular}{lccc}
\hline & $\begin{array}{c}\text { Rain } \\
\text { forest } \\
(\mathrm{N}=203)\end{array}$ & $\begin{array}{c}\text { Ecotype } \\
\text { Derived } \\
\text { savanna } \\
(\mathrm{N}=519)\end{array}$ & $\begin{array}{c}\text { Guinea } \\
\text { savanna } \\
(\mathrm{N}=298)\end{array}$ \\
\hline Trait & & & \\
Body weight $(\mathrm{kg})$ & $1.97 \pm 0.47^{\mathrm{b}}$ & $1.87 \pm 0.56^{\mathrm{a}}$ & $1.89 \pm 0.59^{\mathrm{ab}}$ \\
Body girth $(\mathrm{cm})$ & $41.73 \pm 4.04^{\mathrm{b}}$ & $41.03 \pm 4.94^{\mathrm{ab}}$ & $40.53 \pm 4.79^{\mathrm{a}}$ \\
Body length $(\mathrm{cm})$ & $25.63 \pm 4.67^{\mathrm{a}}$ & $25.93 \pm 3.90^{\mathrm{a}}$ & $25.88 \pm 3.53^{\mathrm{a}}$ \\
Wing length $(\mathrm{cm})$ & $30.06 \pm 5.87^{\mathrm{b}}$ & $28.56 \pm 4.78^{\mathrm{a}}$ & $29.41 \pm 4.46^{\mathrm{ab}}$ \\
Shank length $(\mathrm{cm})$ & $4.95+0.69^{\mathrm{b}}$ & $4.79 \pm 0.77^{\mathrm{a}}$ & $5.02 \pm 0.84^{\mathrm{b}}$ \\
Shank circumference $(\mathrm{cm})$ & $4.69 \pm 0.71^{\mathrm{b}}$ & $4.57 \pm 0.63^{\mathrm{a}}$ & $4.69 \pm 0.56^{\mathrm{b}}$ \\
Thigh length $(\mathrm{cm})$ & $10.95 \pm 1.33^{\mathrm{c}}$ & $10.56 \pm 1.74^{\mathrm{b}}$ & $10.21 \pm 1.34^{\mathrm{a}}$ \\
Bill length $(\mathrm{cm})$ & $5.51 \pm 0.69^{\mathrm{c}}$ & $5.18 \pm 0.57^{\mathrm{a}}$ & $5.31 \pm 0.60^{\mathrm{b}}$ \\
Bill width $(\mathrm{cm})$ & $3.19 \pm 0.34^{\mathrm{a}}$ & $3.20 \pm 0.28^{\mathrm{a}}$ & $3.20 \pm 0.32^{\mathrm{a}}$ \\
Total leg length $(\mathrm{cm})$ & $15.90 \pm 1.93^{\mathrm{b}}$ & $15.35 \pm 2.33^{\mathrm{a}}$ & $15.23 \pm 1.78^{\mathrm{a}}$ \\
\hline
\end{tabular}

${ }^{a b c}$ Means in the same row with different superscripts are different $(p<0.001)$.

highest body weight recorded for rain forest ducks in the present study is consistent with the reports of Yakubu and Ugbo (2010) and Ogah et al. (2011) that rain forest ducks were significantly heavier than their savanna counterparts in Nigeria. Superior body weight of the rain forest Muscovy ducks in relation to others might partially be attributed to the conducive rearing climate mediated through lower ambient temperature and higher precipitation; supporting availability of many water bodies and abundant availability of diverse micro flora and fauna for ducks compared to derived savanna and Guinea savanna AEZs which are drier. Similarly, Yakubu and Ugbo (2010) attributed higher body weight of the rain forest ducks in contrast to Guinea savanna ones to their closeness to the coastal areas, which is favourable to growth of ducks probably as a result of thermoregulatory advantages of being larger in a colder environment. In contrast, lower body weight of ducks in the savanna (derived and Guinea savanna) environment might be an adaptive morpho- logical feature to mitigate challenges posed by the stressful rearing environments engineered by the seasonal scarce food resources and elevated environmental temperature (heat stress factor).

The observed highly significant effect of ecotype on the majority of the morphological traits strongly suggests environmental influence on the morphological attributes of ducks found in different ecotypes. Several studies have shown that morphological variations may result from the phenotypic plasticity in response to the varying environmental conditions (e.g. temperature, salinity, food availability, flow regime, predator/prey interaction etc.) within different geographical areas (Thompson, 1991; Scheiner and Callahan, 1993) or genetic differences or their interactions (Scheiner and Callahan, 1993; Hoffman and Merilä, 1999). Postulating on the possible causes of the observed differences in the morphology of a species, Remerie et al. (2005) reinforced previous assertion that changes in morphological attributes are under the control of 


\section{OGUNTUNJI AND AYORINDE}

environmental conditions or genetic background, or (most often) a combination of both.

Corroborating previous studies, Ouinsavy and Sokpon (2010) asserted that adaptation of a species to diverse environmental challenges may produce different morhphological and physiological characteristics resulting in the development of different ecotypes. Alternatively, morphological differences among co-existing species or morphs within species are often interpreted as a divergent solution; so as to avoid competition by exploiting different resources (Ehlinger and Wilson, 1988; Skulason et al., 1989).

Stepwise discriminant analysis result (table III) indicated that six of the ten morphometric traits; bill length, body girth, wing length, body length, thigh length and shank length contributed significantly $(p<0.001)$ to the separation of the population under study into ecotypes. However, bill length and body length had higher separation power compared to the others.

The highly significant discriminating power of bill length, body length, thigh length, shank length, body girth and wing length implies that consistent measurements of these morphostructural traits would enhance separation of the studied population into distinct ecotypes. It is noteworthy that five of the six most discriminating varia-

Table III. Summary of the step-wise discriminant analysis of the adult Nigerian Muscovy ducks. (Resumen del análisis discriminante secuencial de patos Muscovy nigerianos).

\begin{tabular}{llccc}
\hline Step & $\begin{array}{l}\text { Variable } \\
\text { entered }\end{array}$ & $\begin{array}{c}\text { Wilk's } \\
\text { lambda }\end{array}$ & F-value & $\mathrm{p}>\mathrm{F}$ \\
\hline 1 & Bill length & 0.957 & 23.00 & 0.000 \\
2 & Body length & 0.922 & 21.07 & 0.000 \\
3 & Thigh length & 0.892 & 19.81 & 0.000 \\
4 & Shank length & 0.873 & 17.78 & 0.000 \\
5 & Body girth & 0.864 & 15.38 & 0.000 \\
6 & Wing length & 0.854 & 13.81 & 0.000 \\
\hline
\end{tabular}

bles, except body girth, are measures of length and are environmentally independent, thus indicating inherent size. Non sensitivity of the five of the six discriminating variables to the prevailing environmental factors substantiated further the reliability and suitability of such traits in separating ducks into distinct clusters.

Comparison of the discriminating variables reported in this study and previous ones on Muscovy ducks in Nigeria revealed disparities. Ogah et al. (2011) reported body weight, body width, body lenght and wing length as the most discriminating variables for ducks sampled in the rain forest, Guinea savanna and dry savanna while foot length, neck length, thigh circumference and body length were the most discriminating variables for Muscovy ducks sampled in rain forest and Guinea savanna (Yakubu and Ugbo, 2010).

Differences observed in the discriminating variables in those studies and the present one might be attributed to the differences in the study areas, data collection methods, number of variables measured and sample sizes. The highest discriminating power of bill length in the present study compared to other morphological variables might be attributed to its trophic nature, putting into consideration the amphibious nature of Muscovy ducks. This might be an adaptive feature for harvesting terrestrial and aquatic food materials since food availability varies from season to season across the agro-ecological zones and also for defence against both aquatic and terrestrial predators that might want to take advantage of the sluggish nature of ducks.

The classification result, validated by cross-validation test (table IV) showed that $41.8,53.7$ and $42.3 \%$ of the derived savanna, rain-forest and Guinea savanna ducks were correctly classified into their separate ecotypes. On the average, discriminant analysis of morphostructural traits correctly classified $44.3 \%$ of the studied population.

Low classification success rate in using 


\section{MULTIVARIATE ANALYSIS OF MUSCOVY DUCKS}

morphological traits for separation of Muscovy ducks into different ecotypes in the present study agrees with the report of Yakubu and Ugbo (2010) that small morphological differences exists between Guinea savanna and rain forest Muscovy ducks. In contrast, Ogah et al. (2011) reported higher classification success rate and correctly classified 71.9, 85.4 and 94.9\% of Guinea savanna, dry savanna and rain forest Nigerian Muscovy ducks respectively, into their expected ecotypes.

A major possible reason for low classification success rate of ducks into separate ecotypes in the present study might be attributed to the absence of selection within ecotypes. In addition, the unrestricted gene flow between ducks of different ecotypes through inter-regional trade; and human movement promotes indiscriminate mating and exchange of genetic materials among ducks of different ecotypes. In addition, the

Table IV. Classification results of the discriminant analysis. (Resultados de la clasificación de análisis discriminante).

\begin{tabular}{|c|c|c|c|c|}
\hline & \multicolumn{4}{|c|}{ Predicted ecotype membership } \\
\hline & $\begin{array}{c}\text { Derived } \\
\text { savanna } \\
\mathrm{N}=519\end{array}$ & $\begin{array}{c}\text { Rain } \\
\text { forest } \\
\mathrm{N}=203\end{array}$ & $\begin{array}{c}\text { Guinea } \\
\text { savanna } \\
\mathrm{N}=298\end{array}$ & $\begin{array}{c}\text { Total } \\
\mathrm{N}=1020\end{array}$ \\
\hline \multicolumn{5}{|c|}{ Original, count } \\
\hline 1 & 221 & 138 & 160 & 519 \\
\hline 2 & 39 & 118 & 46 & 203 \\
\hline 3 & 78 & 81 & 139 & 298 \\
\hline \multicolumn{5}{|l|}{$\%$} \\
\hline 1 & 42.6 & 26.6 & 30.8 & 100 \\
\hline 2 & 19.2 & 58.1 & 22.7 & 100 \\
\hline 3 & 26.2 & 27.2 & 46.6 & 100 \\
\hline \multicolumn{5}{|c|}{ Cross-validated, count } \\
\hline 1 & 217 & 138 & 164 & 519 \\
\hline 2 & 45 & 109 & 49 & 203 \\
\hline 3 & 83 & 89 & 126 & 298 \\
\hline \multicolumn{5}{|l|}{$\%$} \\
\hline 1 & 41.8 & 26.6 & 31.6 & 100 \\
\hline 2 & 22.2 & 53.7 & 24.1 & 100 \\
\hline 3 & 27.9 & 29.9 & 42.3 & 100 \\
\hline
\end{tabular}

Table V. Euclidean genetic distance between Nigerian Muscovy duck ecotypes. (Distancia euclidiana entre los ecotipos de patos Muscovy nigerianos).

\begin{tabular}{lccc}
\hline & $\begin{array}{c}\text { Rain } \\
\text { forest }\end{array}$ & $\begin{array}{c}\text { Derived } \\
\text { savanna }\end{array}$ & $\begin{array}{c}\text { Guinea } \\
\text { savanna }\end{array}$ \\
\hline Rain forest & 0.000 & 2.010 & 3.758 \\
Derived savanna & 2.010 & 0.000 & 3.147 \\
Guinea savanna & 3.758 & 3.147 & 0.000 \\
\hline
\end{tabular}

high assignment error in separation of ducks to distinct ecotypes is an indication of low intraspecific variation in spite of geographical separation in their sources. It also suggested that sampled ducks, though found in different AEZs, possibly originated or had common ancestors. It is imperative to state that the high assignment error in classifying ducks into distinct ecotypes in this study is a pointer to inadvertent but remarkable influence of socio-economic activities on genetic attributes of the Nigerian Muscovy ducks.

The Euclidean distance measure between the studied sub-populations was small (table V); shortest distance (2.010) was between the rain forest and derived savanna ducks, longest (3.758) between the rain forest and Guinea savanna but intermediate (3.147) between the rain forest and derived savanna ducks.

Though the phenotypic distances between the ecotypes were low in this study, nevertheless, a unique observed trend was an increasing genetic distance as the geographical distance was increasing between ecotypes. The geographical proximity of the rain forest and derived savanna agro-ecological zones in contrast to the long distance to Guinea savanna encouraged intermingling of ducks from the two ecotypes. It has been shown that phenotypic differences are maintained in part by the reduction of gene flow among populations separated by large distances 
(Yakubu and Ibrahim, 2011). Substantiating influence of geographical distance between members of a species on genetic similarity and disimmilarity; Salako and Ngere (2002) attributed small genetic distance between two Nigerian indigenous goat breeds to genetic exchange which occurred between them because the overlapping nature of their geographical distribution has reduced the genetic distance that would theoretically have described their differences. It is suggestive from this trend that wider geographical distance between members of a species encourages genetic purity and conservation of distinct identity.

Furthermore, the short phenotypic distance observed among duck ecotypes in the present study is in agreement with the recent reports of Yakubu and Ugbo (2010) and Ogah et al. (2011) on Nigerian Muscovy ducks and also attests further to the high assignment error of classification of ducks into distinct ecotypes. In a related study, Ajayi et al. (2012) also reported low genetic distance between three genotypes of Nigerian local chickens.

The short phenotypic distance in morphological traits between ecotypes is suggestive that appreciable heterosis in these morphological traits is not feasible through crossbreeding of Nigerian Muscovy ducks originating from different ecotypes. Wide genetic distance between parental groups is fundamental to higher

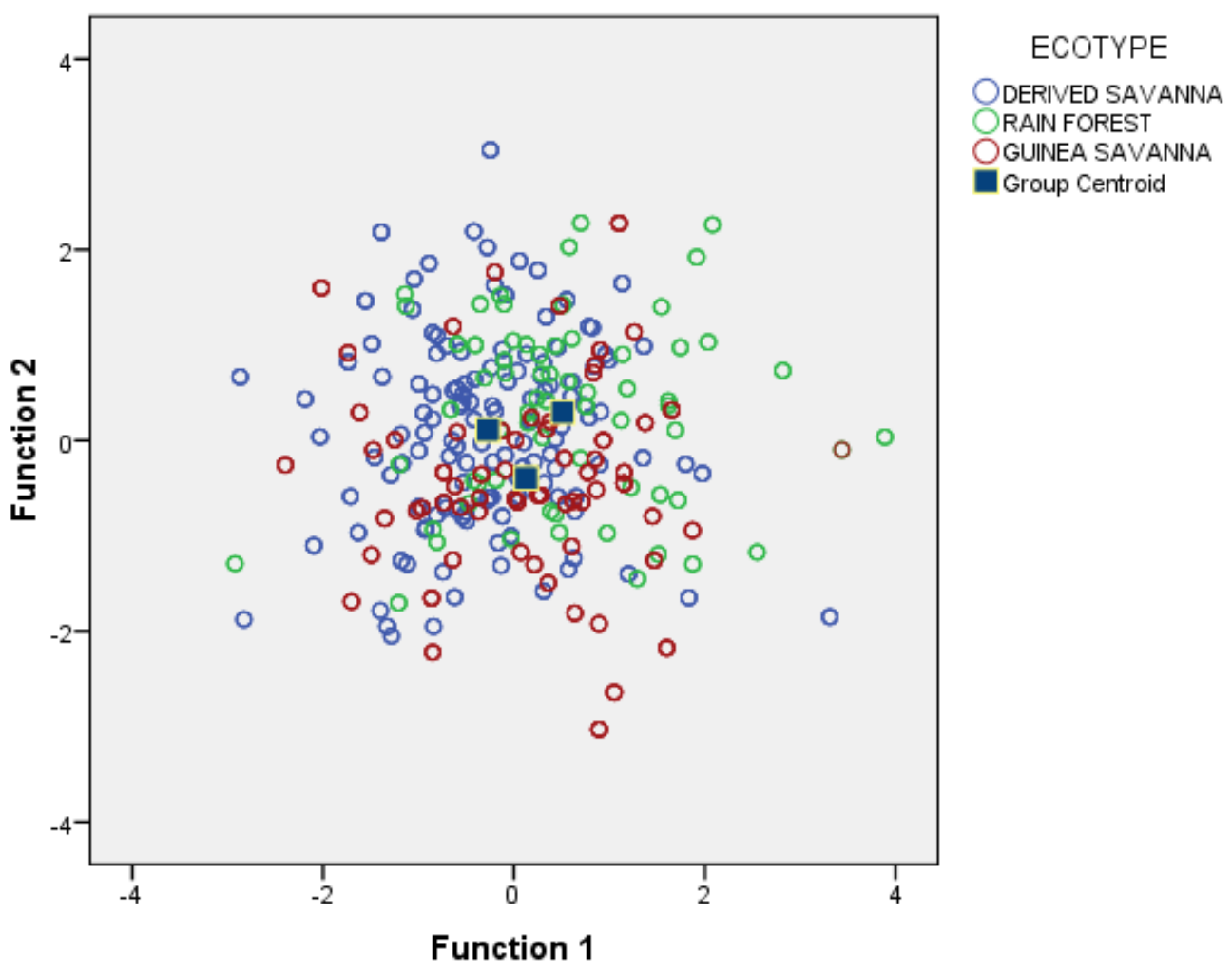

Figure 1. Cannonical representation of the Nigerian Muscovy duck ecotypes. (Representación canónica de ecotipos de patos Muscovy nigerianos). 


\section{MULTIVARIATE ANALYSIS OF MUSCOVY DUCKS}

heterosis/hybrid vigour. Since heterosis exploits wide genetic differences between parental groups; therefore, the wider the genetic bases the higher the heterosis and vice versa. Though morphological distances are likely to grossly under-estimate true levels of genetic variation between populations, it is capable of providing a sound foundation and reference in the systemic evaluation and characterization of our indigenous species (Salako and Ngere, 2002).

The canonical plot representation for the clusters formed by the Muscovy duck ecotypes is shown in figure 1. Corroborating low genetic distance between ecotypes (table IV), the canonical plot representation of the ecotypes revealed high intermingling of the ecotypes, resulting in the absence of distinct clusters. Besides, proximity of the group centroids attests further to the low morphological differentiation between ecotypes and is also an indication of homogeneity in the morphological attributes of the studied sub-populations. In tandem with the result of this study, previous attempts on morphological differentiation of three Nigerian indigenous chicken

\section{REFERENCES}

Adesope, O.M. and Nodu, M.B. 2002. A note on acceptance of duck as table-meat among inhabitants of selected communities in the Niger Delta zone, Nigeria. Livest Res Rural Dev, 14(6). http://www.Irrd.org//rrd14/6/ades146.htm (19/ 07/2013).

Adeyemi, O.A.; Sobayo, R.A. and Aluko, F.A. 2008. A survey of duck farming activities in Abeokuta metropolis of Ogun State, Nigeria. Nig Poultry Sci J, 5: 23-29.

Agaviezor, B.O.; Peters, S.O.; Adefenwa, M.A.; Yakubu, A.; Adebambo, O.A.;Ozoje, M.O.; Ikeobi, C.O.N.; Wheto, M.; Ajayi, O.O.; Amusan, S.A.; Ekundayo, J.O.; Sanni, T.M.; Okpeku, M.; Onasanya, G.O. and De Denato, M. 2012. Morphological and microsatellite DNA diversity of Nigerian indigenous sheep. J Anim Sci Biotechnol. http://www.jasbsci.com/content/3/ 1/38. 28 pp. (12/09/2013). genotypes (Ajayi et al., 2012) and two ecotypes of Nigerian Moscovy ducks (Yakubu et al. 2011) yielded no discrete clusters.

\section{CONCLUSION}

This study provided additional information on the characterisation of the Nigerian Muscovy ducks based on morphostructural traits. It is evident in this study that Nigerian Muscovy ducks are homogenous morphologically though found in different ecotpes.

Though the Nigerian Muscovy ducks used in this study were drawn from different ecological zones; nevertheless, based on the estimated phenotypic distance and cross validaton result of discriminant analysis they could not not be classified into distinct strains or ecotypes based on morphological traits. Application of blood protein markers and highly informative DNA analysis could be of immense contribution to elucidation of the inherent genetic differences in Nigerian Muscovy duck found across agroecological zones in Nigeria.

Ajayi, O.O.; Adeleke, M.A.; Sanni, M.T.; Yakubu, A.; Peters, S.O.; Imumorin, I.K.; Ozoje, M.O.; Ikeobi, C.O.N. and Adebambo, O.A. 2012. Application of principal component and discriminant analyses to morpho-structural indices of indigenous and exotic chickens raised under intensive management system. Trop Anim Health Pro, 44: 1247-1254.

Al-Atiyat, R. 2009. Diversity of chicken populations in Jordan determined using discriminate analysis of performance traits. Int J Agric Biol, 11: 374380.

Dossa, L.H.; Wollny, C. and Gauly, M. 2007. Spatial variation in goat populations from Benin as revealed by multivariate analysis of morphological traits. Small Ruminant Res, 73: 150-159.

Ehlinger, E.J. and Wilson, D.S. 1988. Complex foraging polymorphism in bluegill sunfish. Proc Natl Acad Sci (USA), 85: 1878-1882. 


\section{OGUNTUNJI AND AYORINDE}

Herrera, M.; Rodero, E.; Gutierrez, M.J.; Peña, F. and Rodero, J.M. 1996. Application of multifactorial discriminant analysis in the morphostructural differentiation of Andalusian caprine breeds. Small Ruminant Res, 22: 39-47.

Herring, G.; Ackerman, J.T.; Eagles-Smith, C.A. and Takekawa J.Y. 2010. Sexing California gulls using morphometrics and discriminant function analysis. Waterbirds, 33: 79-85.

Hillel, J.; Groenen, M.A.; Tixier-Boichard, M.; Korol, A.B.; David, L.; Kirzhner, V.M.; Burke, T.; BarreDirie, A.; Crooijmans, R.P.; Elo, K.; Feldman, M.W.; Freidlin, P.J.; Maki-Tanila, A.; Oortwijn, M.; Thompson, P.; Vignal, A.; Wimmers, K. and Weigend, S. 2003. Biodiversity of 52 chicken populations assessed by microsatellite typing of DNA pools. Genet Sel Evol, 35: 533-557.

Hoffman, A.A. and Merilä, J. 1999. Heritable variation and evolution under favourable and unfavourable conditions. Trends Ecol Evol, 14: 96-101.

Kharel, M. and Arboleda, C.R. 1986. Some genetic factors responsible for body growth in Muscovy duck. Nepal J Inst Agric Anim Sci, 7: 101-110.

Liordos, V. and Goutner, V. 2008. Sex determination of great cormorants (Phalacrocorax carbosinensis) using morphometric measurements. Waterbirds, 31: 203-210.

Lix, L.M. and Sojobi, T.T. 2010. Discriminant analysis for repeated measured data: A Review. Psychology, 1: 146. Doi: 10.3389/fpsy.

McCracken, K.G.; Paton, D.C. and Afton, A.D. 2000. Sexual dimorphism of the Musk duck. Wilson Bull, 112: 457-466.

NBS. 2012. National Bureau of Statistics/Federal Ministry of Agriculture and Rural Development Collaborative Survey on National Agriculture Sample Survey (NASS), 2010/2011-Draft Report. May, 2012.

Nwanta, J.A.; Umoh, J.U.; Abdu, P.A.; Ajogi, I. and Ali-Balogun, J.K. 2006. Management of losses and Newcastle disease in rural poultry in Kaduna State. Nig J Anim Prod, 33: 274-285.

Ogah, D.M.; Momoh, M.O. and Dim, N.I. 2011. Application of canonical discriminat analysis for assessment of genetic variation in Muscovy duck ecotypes in Nigeria. Egyptian Poultry Sci, 31: 429-436.

Oguntunji, A.O. 2013. Phenotypic and biochemical characterization of the Nigerian Muscovy ducks. Ph. D. Dissertation. Bowen University. Iwo.
Osun State. Nigeria. 333 pp.

Oguntunji, A.O.; Aderemi, F.A.; Lawal, T.E. and Alabi, O.M. 2008. The influence of seasonal variation on performance of a commercial laying strain in a derived savanna environment in Nigeria. Nig Poultry Sci J, 5: 75-82.

Ouinsavy, C. and Sokpon, N. 2010. Morphological variation and ecological structure of iroko (Milicia excelsa Welw. C.C. Berg). Populations across different biogeographical zones in Benin. Intl J Forestry Res. Article ID 658396.10 pp. doi: 10.1155/2010/658396.

Remerie, T.; Bourgois, T. and Vanreusel, A. 2005. Morphological differentiation between geographically separated populations of Neomysis integer and Mesopodopsis slabberi (Crustacea, Mysida). Hydrobiologia, 549: 239-250.

Romanov, M.N. and Weigend, S. 2001. Analysis of genetic relationships between various populations of domestic and jungle fowl using microsatellite markers. Poultry Sci, 80: 10571063.

Salako, A.E. and Ngere, L.O. 2002. Application of multifactorial discriminant analysis in the Morphometric structural differentiation of the WAD and Yankasa sheep in the humid southwest Nigeria. Nig J Anim Prod, 29: 163-167.

Scheiner, S.M. and Callahan, H.S. 1993. Measuring natural selection on phenotypic plasticity. Evolution, 53: 1704-1713.

Skulason, S.; Noakes, D.L. and Snorrason, S.S. 1989. Ontogeny of trophic morphology in four sympatric morphs of arctic cham Salvelinus alpinus in Thingvallavatn, Iceland. Biol J Linn Soc, 38: 281-301.

SPSS. 2001. Statistical Package for Social Sciences. SPSS Inc. 444 Michigan Avenue. Chicago, IL60611.

Tabachnick, B.G. and Fidell, L.S. 2007. Using multivariate statistics, $5^{\text {th }}$ ed. Allyn and Bacon. Boston, Massachusetts. 980 pp.

Thompson, J.D. 1991. Phenotypic plasticity as a component of evolutionary change. Trends Ecol Evol, 6: 246-249.

Traoré, A.; Tamboura, H.H.; Kaboré, A.; Royo, L.J.; Fernandez, I.; Avarez, I.; Sangaré, M.; Bouchel, D.; Poivey, J.P.; Francois, D.; Toguyeni, A.; Sawadogo, L. and Goyache, F. 2008. Multivariate characterization of morphological traits in Burkina Fasso sheep. Small Ruminant 


\section{MULTIVARIATE ANALYSIS OF MUSCOVYDUCKS}

Res, 80: 62-67.

Wimmers, K.; Ponsuksili, S.; Hardge, T.; ValleZarate, A.; Marthur, P.K. and Horst, P. 2000. Genetic distinctness of African, Asian and South American local chickens. Anim Genet, 31: 159-165.

Wu, R. and Lin, M. 2006. Functional mapping-how to map and study the genetic architecture of dynamic complex traits. Nature Rev Genet, 7: 229-237.

Yakubu, A. and Ugbo, S.B. 2010. An assessment of biodiversity in morphological traits of Muscovy ducks in Nigeria using discriminant analysis. Intl Conf Biol Envt Chem IPCBEE IACSIT Press, Singapore, 1: 389-391.
Yakubu, A.; Idahor, K.O.; Haruna, H.S.; Wheto, M. and Amusan, S. 2010. Multivariate analysis of phenotypic differentiation in Bunaji and Sokoto Gudali cattle. Acta Agric Slovenica, 96: 75-80.

Yakubu, A. 2011. Discriminant analysis of sexual dimorphism in morphological traits of African Muscovy ducks. Arch Zootec, 60: 1-8.

Yakubu, A. and Ibrahim, I.A. 2011. Multivariate analysis of morphostructural characteristics in Nigerian indigenous sheep. Italian J Anim Sci, 10: 83-86.

Yakubu, A.; Kaankuka, F.G. and Ugbo, S.B. 2011. Morphological traits of Muscovy ducks from two agro-ecological zones of Nigeria. Tropiculura, 29: 121-124. 